\title{
The measurement model of geo-education among trainee teachers in Malaysia
}

\author{
Mat Rahimi Yusof ${ }^{1}$, Mohd Faiz Mohd Yaakob ${ }^{2}$, Aliff Nawi ${ }^{3}$, Hapini Awang ${ }^{4}$, Dayang Rafidah Syariff \\ M. Fuad ${ }^{5}$, Aizuddin Md Rami ${ }^{6}$ \\ ${ }^{1,2,3,4}$ School of Education, Universiti Utara Malaysia, Malaysia \\ ${ }^{5}$ Faculty of Management and Economics, Universiti Pendidikan Sultan Idris, Malaysia \\ ${ }^{6}$ Faculty of Educational Studies, Universiti Putra Malaysia, Malaysia
}

\section{Article Info}

Article history:

Received Sep 29, 2020

Revised Mar 8, 2021

Accepted Apr 11, 2021

\section{Keywords:}

Elements across the curriculum Environmental education Geo-education

\begin{abstract}
This study conducted to develop a measurement model for measuring GeoEducation in Malaysia context. This cross-sectional survey involved 245 trainee teachers in Universities and Institute Pendidikan Guru Malaysia (IPGM). The data collection was made through a set of questionnaires and analyzed using SEM-AMOS. There are four main elements measured, which are loading factors, convergent validity, discriminant validity, and composite reliability. The findings indicated that Geo-Education had a significant contribution to the proposed constructs, namely primer, issues, ecosystem, lifestyle, and cross-curricular elements. A model of Geo-Education was successfully developed in this study using these five constructs, namely primer, issues, ecosystem, lifestyle, and cross-curricular elements. This study also identified 25 behaviors of Geo-Education among the trainee teachers in Malaysia. The findings of this study are essential as a guideline for Malaysian teachers to implement the concept of Geo-Education in Malaysia. Additionally, the application of this subject as cross-curricular elements in the Malaysian curriculum is essential to ensure the success of the implementation of Education Sustainable Development (ESD) in the school environment.
\end{abstract}

This is an open access article under the CC BY-SA license.

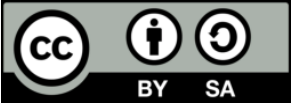

\section{Corresponding Author:}

Mat Rahimi Yusof

School of Education

Universiti Utara Malaysia

06010, UUM Sintok, Kedah, Malaysia

Email: rahimi@gurumalaysia.edu.my

\section{INTRODUCTION}

The word 'Geo' comes from the Greek word meaning 'earth.' Thus, this word also related to the meaning of ground, global, or anything related to land. Nowadays, the Geo concept had widely been researched as in Geo-heritage; Geo-conservation; Geo-sites or Geo-parks; Geo-Management; Geo-Diversity; Geo-Tourism; and Geo-Education [1]. In the context of education, Geo-Education is a globally recognized environmental education that gives the current generation a basic understanding of how the human world and the environment function in local, regional, and global contexts [2].

Generally, Geo-Education is a process of disclosing information to develop students' concerns, abilities, attitudes, and values. This process enables greater engagement of teachers and students at the local, national, and international levels. It helps them to work together towards a more sustainable future. This is due to the educational elements as a key to transforming society for a better community and as an essential medium to achieve the objectives stated in the Sustainable Development Goal [3]-[6]. 
In the Malaysian context, Geo-Education research is still scarce in the community. The concept of Geo-Education poorly introduced and explained to the community. The Geo-education concept had a similarity with Environmental Education, and it needs to rebrand in response to the United Nations Sustainable Development Goals (SDG, 2019) [7]. The idea of Geo-Education has also applied in the tourism industry, such as Langkawi UNESCO Global Geopark, which contributes to the international sustainability of the foreign and domestic tourism industry.

\section{PROBLEM STATEMENT}

In Malaysia, Environmental Education was formally implemented through a well-planned curriculum in 1983 with the New Elementary School Curriculum (KBSR). Then, the changes in the Primary School Curriculum (KSSR) in 2012 had shed new light on the Environmental Education, where it was introduced as Cross-Curricular Elements (EMK) in 2017 through global sustainability. However, in reality, the implementation of environmental values has not been fully implemented by the teachers in their teaching and learning sessions, and the students also have not fully understood it [8]-[10].

This situation is due to the lack of specific guidelines and guidance from the environmental care professionals about the right way to protect the environment, and to make things worse; they neglected the ecological aspects of sustainability [3], [11]. As a consequence, the misunderstanding of the concept of sustainable education in the environment had caused a lack of emphasis on this concept in education [12][14]. The lack of awareness of information on the implementation of sustainable development in consumer life also affects the achievement of the Sustainable Development Goals (SDGs) [15]. This shows that exposure to Geo-Education is particularly crucial in addressing a lack of information on how it should implement in teaching and learning in schools [16].

However, in the research context, especially in the Malaysian context, there are only a few researchers focused on sustainable development in their research [6]. According to a report from the Department of Environment, the lack of clear information on implementing sustainable development is one of the reasons why sustainable development stalled [16]. Therefore, based on these issues and concerns, it is recommended that local researchers undertake a study on Geo-Education.

\section{LITERATURE REVIEW}

Sustainable education is a need in education for its importance in local and international interest. UNESCO had taken this coordination seriously. It is involved creatively built, handling the global and future issues creatively, and be able to develop a more sustainable and resilient society [17]. In particular, sustainable education enables students to integrate environmental considerations in making more wise decisions [18].

The world associations also used the Education Sustainable Development (ESD) approach in the context of education through the conference of The World Conservation Union (IUCN) with the concept of "education for sustainable living" in the late 1990s [19], [20]. Today, the world association through the United Nations continues to focus on the ESD implementation by launching the United Nations Decade of Education for Sustainable Development (2005-2014). They emphasized on all countries on the importance of integrating sustainable development principles, values, and practices into all aspects of education and learning [21]. However, few issues are surrounding this implementation, such as issues with the education for sustainable development (ESD). The ESD is generally a process to develop students' concerns, abilities, attitudes, and values. This process enables their involvement in sustainable development more effectively locally, nationally, and internationally and helps them work together towards a more sustainable future.

Therefore, education can act as a powerful tool to resolve all these issues regarding environmental concerns. Educational can play a significant role in transforming the mindset of the society and serve as an essential medium in sustainable development [4], [5], [22], [23].

\section{RESEARCH METHOD}

This quantitative study employed cross-sectional survey design. The quantitative approach using questionnaires deems reasonable in the large population and respondents [24]. The measurement model of Geo-Education developed based on five constructs, which are primer, issues, ecosystem, lifestyle, and curricular cross element. The secondary objectives are to analyses the relationship between Geo-Education and the five constructs in the model, and the third objectives are to confirm the constructs and indicators (behaviors) in Geo-Education Module. 
Data was collected from 245 respondents using a set of questionnaires using ten scale responses. The lowest scale range from extremely disagrees to extremely agree. The surveys divide into five parts which are primer, issues, ecosystem, lifestyle, and cross-curricular elements. The reliability coefficients of all the constructs ranged from 0.84 to 0.88 , and the Alpha Cronbach's value for the whole questionnaire is 0.94.

Data were analyzed using SPSS Structural Equation Modelling (SEM) that applied AMOS software. A confirmatory factor analysis (CFA) used to analyze the measurement model. This procedure used to determine the loading factor, convergent validity, composite reliability, and discriminant validity in the measurement model. Therefore, the proposed factor is acceptable if the regression weight $(\beta)$ for the factor loading value is 0.708 [25], [26]. According to Hair, et al. [25], the external load value $\geq 0.4$ is acceptable if the AVE value reaches the recommended value of $>0.5$. The composite reliability is acceptable if the value $>0.708$. The average variance extracted (AVE) value at 0.5 or above, and the composite reliability (CR) values are at 0.708 or above. The values of AVE's square root must be higher than the inter-correlation values between constructs or items for the discriminant [27]-[29]

The fitness of the model tested using several fit indices such as Chi Square (CMIN), CFI, RMSEA, PNFI and PCFI. The hypothesis model considered fit with the collected data when the significant values of Chi Square (CMIN) exceeding 0.05. The hypothesis model also considered fit when the CFI is exceeding 0.90 , but values between 0.80 and 0.89 are still in the acceptable margin. The RMSEA acceptable value is lower than 0.08, but it is still acceptable if less than 0. [30], [31]. The PCFI and PNFI index values must exceed 0.5 for the fit of the model [32]. The final model considered fit if at least one of each category of absolute relative and parsimony indexes were fit.

\section{RESULTS AND DISCUSSION}

The findings showed in Table 1 indicates the descriptive findings of the normality, convergence validity, and composite reliability. It also shows the correlation between Geo-Education and the five constructs, which are primer, issues, ecosystem, lifestyle, and curricular cross elements. The findings showed that all the variables reached convergent validity (AVE>0.5), composite reliability (CR>0.701), discriminant validity (square root $\mathrm{AVE}>$ correlation values between variables), and data normality (skewness and kurtosis values between -1 and +1 ). The findings also showed that all variables have a strong correlation with each other [27].

Table 1. Preliminary results

\begin{tabular}{lccccccccc}
\hline \multicolumn{1}{c}{ Constructs } & Mean & SD & Skew & Kurt & 1 & 2 & 3 & 4 & 5 \\
\hline Primer & 8.91 & 1.19 & -1.33 & 1.56 & $\mathbf{0 . 8 7 2}$ & & & & \\
Issue & 8.96 & 1.16 & -1.46 & 2.6 & 0.812 & $\mathbf{0 . 8 2 5}$ & & & \\
Ecosystem & 9.34 & 1 & -2.03 & 4.35 & 0.96 & 0.66 & $\mathbf{0 . 8 8 2}$ & & \\
Life Style & 9.32 & 1.03 & -2.03 & 4.63 & 0.896 & 0.61 & 0.64 & $\mathbf{0 . 9 6 2}$ & \\
Co-curricular Cross Element & 9.02 & 1.27 & -1.95 & 5.27 & 0.797 & 0.828 & 0.94 & 0.741 & $\mathbf{0 . 9 9 5}$ \\
\hline Note: SQRT AVE value (bold) shown in prints. & & & & & & &
\end{tabular}

Table 2 represents the second objectives of this study. It shows the values of critical ratio (C.R.) of the Geo-Education that contributes significantly on the constructs. Life style $(\beta=.057, C . R=16.157, P=.000)$, Curricular Cross Element $(\beta=.074, C . R=15.094, P=.000$, Ecosystem $(\beta=.049, C . R=15.496, P=.000)$, Primer $(\beta=.069, C . R=13.050, P=.000)$, and Issue $(\beta=.075, C . R=13.789, P=.000)$.

Table 2. Regression coefficient result

\begin{tabular}{cccccccc}
\hline Constructs & & Variable & Estimate & S.E. & C.R. & P & Label \\
\hline Life style & $<---$ & Geo-Education & .915 & .057 & 16.157 & $* * *$ & Significant \\
Curricular cross element & $<---$ & Geo-Education & 1.112 & .074 & 15.094 & $* * *$ & Significant \\
Ecosystem & $<---$ & Geo-Education & .759 & .049 & 15.496 & $* * *$ & Significant \\
Primer & $<---$ & Geo-Education & .900 & .069 & 13.050 & $* * *$ & Significant \\
Issue & $<---$ & Geo-Education & 1.037 & .075 & 13.789 & $* * *$ & Significant \\
\hline
\end{tabular}

Table 3 shows the validation of the Geo-Education module confirmatory factor analysis. It showed that the confirmatory factor analysis (CFA) was at the accepted value. The findings showed that the factor loading (FA), composite reliability (CR), average variant extractor (AVE), and square root AVE ( $\sqrt{ }$ AVE) for each construct were achieved and acceptable. Thus, the findings of this study can answer the confusion on 
the concept of sustainable education in the environment also causes this is not given good emphasis [33]. Table 3 showed the value of FL, CR, AVE and $\sqrt{ }$ AVE for the primer constructs (FL $=0.817-0.932$, $\mathrm{CR}=0.941, \mathrm{AVE}=0.761$, SQRT AVE=0.872).

Table 3. The summary analysis for primer construct

\begin{tabular}{ccllccc}
\hline Construct & Items & \multicolumn{1}{c}{ Indicators } & FL & CR & AVE & VAVE \\
\hline P1 & P2 & $\begin{array}{l}\text { The introduction of Geo-Education is necessary to the } \\
\text { practicum teacher through the module. } \\
\text { There is a need for learning outcomes for the Geo-Education } \\
\text { module }\end{array}$ & 0.932 \\
Primer & P3 & $\begin{array}{l}\text { Technology applications need to be implemented in Geo- } \\
\text { Education } \\
\text { Pn appropriate approach should be used for the Geo- }\end{array}$ & 0.858 & 0.941 & 0.761 \\
P4 & $\begin{array}{l}\text { Education module } \\
\text { Geo-Education needs to be understood by the trainee teacher }\end{array}$ & 0.817 \\
P5
\end{tabular}

Table 4 shows the values of FL, CR, AVE, and SQRT AVE for the Ecosystem construct. The findings indicated that the values of $F L=0.832-0.922, \mathrm{CR}=0.778$, SQRT AVE=0.882, as shown in Table 4. Table 5 shows the values of FL, CR, AVE, and SQRT AVE for the Cross-Curricular elements construct ( $\mathrm{FL}=0.833-0.938, \mathrm{CR}=0.900, \mathrm{AVE}=0.809$, SQRT AVE=0.955). Table 6 showed the values of FL, CR, AVE and SQRT AVE for Life Style construct (FL=0.8840.951, CR=0.914, AVE=0.835, SQRT AVE=0.962). Table 7 shows the values of FL, CR, AVE and SQRT AVE for Issue construct (FL=0.8840.951, CR=0.7810.864, $\mathrm{CR}=0.914, \mathrm{AVE}=0.680, \mathrm{SQRT}$ AVE=0.825).

Table 4. The CFA analysis of ecosystem constructs

\begin{tabular}{|c|c|c|c|c|c|c|}
\hline Construct & Items & Indicators & FL & $\mathrm{CR}$ & AVE & $\sqrt{\mathrm{AVE}}$ \\
\hline \multirow{3}{*}{ Ecosystem } & ED1 & The natural ecosystem is an important part of Geo-Education & 0.832 & \multirow{3}{*}{0.941} & \multirow{3}{*}{0.761} & \multirow{3}{*}{0.872} \\
\hline & ED3 & The ecosystem needs to be well maintained & 0.922 & & & \\
\hline & ED5 & We entrusted with the care of the natural ecosystem & 0.893 & & & \\
\hline
\end{tabular}

Table 5. The CFA analysis for co-curricular cross element

\begin{tabular}{cclccc}
\hline Construct & Items & \multicolumn{1}{c}{ Indicators } & FL & CR & AVE \\
& M1 & Geo-Education can be taught on a variety of subjects & 0.833 & \\
& M2 & Geo-Education can cross the curriculum & 0.927 & \\
Co-curricular & M3 & Various techniques can be introduced for teaching Geo-Education & 0.908 & 0.900 & 0.809 \\
cross elements & M4 & $\begin{array}{l}\text { Geo-Education fits in with the elements across the curriculum } \\
\text { M5 }\end{array}$ & $\begin{array}{l}\text { Geo-Education is ideal for teaching and learning all subjects in } \\
\text { schools }\end{array}$ & 0.938 & 0.888 \\
\hline
\end{tabular}

Table 6. The CFA analysis for lifestyle

\begin{tabular}{|c|c|c|c|c|c|c|}
\hline Construct & Items & Indicators & FL & $\mathrm{CR}$ & AVE & $\sqrt{\mathrm{AVE}}$ \\
\hline \multirow{5}{*}{ Life style } & G1 & We need to understand a sustainable lifestyle & 0.946 & \multirow{5}{*}{0.914} & \multirow{5}{*}{0.835} & \multirow{5}{*}{0.962} \\
\hline & $\mathrm{G} 2$ & Sustainable lifestyles need to be practiced by us & 0.951 & & & \\
\hline & G3 & Sustainable living is very important to us & 0.934 & & & \\
\hline & G4 & Nature needs us to take good care of it & 0.849 & & & \\
\hline & G5 & $\begin{array}{l}\text { The development of technology needs to be consistent with a } \\
\text { sustainable lifestyle }\end{array}$ & 0.884 & & & \\
\hline
\end{tabular}

Table 7. The CFA analysis for issues

\begin{tabular}{|c|c|c|c|c|c|c|}
\hline Construct & Items & Indicators & FL & $\mathrm{CR}$ & AVE & $\sqrt{\mathrm{AVE}}$ \\
\hline \multirow{4}{*}{ Issues } & S1 & There are issues that are frequently debated in Geo-Education & 0.834 & \multirow{4}{*}{0.914} & \multirow{4}{*}{0.68} & \multirow{4}{*}{0.825} \\
\hline & $\mathrm{S} 2$ & Geo-Education is happening all around us & 0.815 & & & \\
\hline & $\mathrm{S} 3$ & Environmental pollution is a major issue of Geo-Education & 0.781 & & & \\
\hline & S5 & Geo-Education issues are very relevant to educational institutions & 0.828 & & & \\
\hline
\end{tabular}


Figure 1 shows the measurement of the Geo-Education model that successfully developed. This model developed using the five constructs above, which are Primer, Ecosystem, Cross-Curricular elements, Lifestyle, and Issue. This model also showed the accepted 25 behaviors or indicators in Geo-Education among the trainee teachers in Malaysia. In the context of quality education, sustainable development should be embedded in teaching and learning by using this model. The emphasis and appreciation of sustainable development in education should be given the priority in addressing sustainability issues because education plays a crucial role in addressing all of the goals of SDG-4 [34].

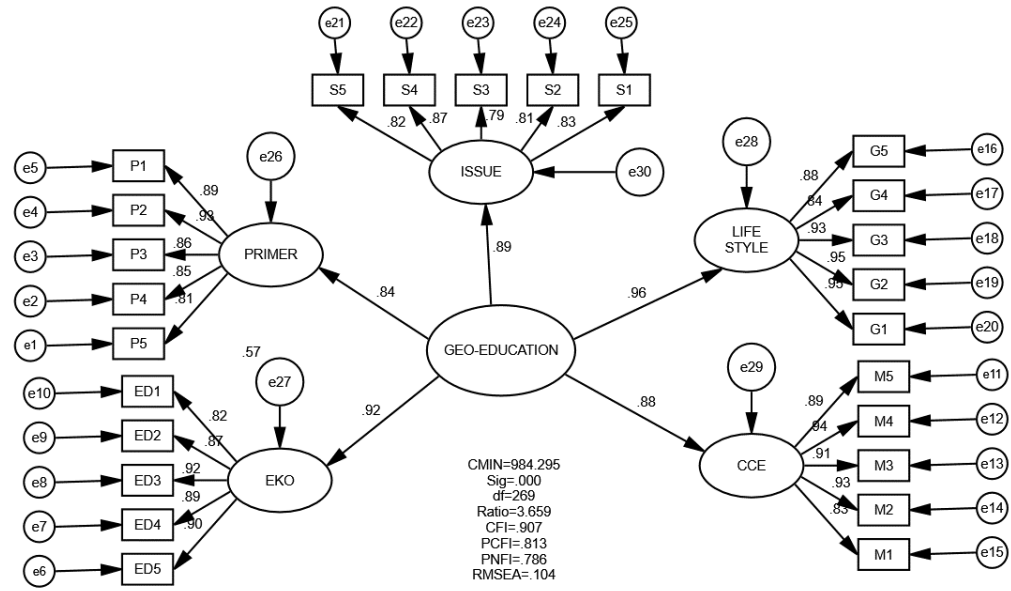

Figure 1. The Geo-Education management model

\section{CONCLUSION}

Since 2010, the Malaysian educational department had provided modules and materials for Environmental Education to be carry on in the curriculum. However, the implementation and exposure of this education in school is still not enough and lacking in various aspects. This study had successfully identified five constructs and 25 specific indicators or the behaviors of Geo-Education as a guideline for the implementation of environmental education care in Malaysia schools. The findings also can ease the misunderstanding arise regarding the concept of sustainable education in the environment.

Furthermore, this study intended to provide clear guidelines for Malaysian teachers to implement Geo-Education in schools. Additionally, the implementation of the cross-curricular elements in our teaching and learning process can contribute to significant changes in the implementation of this education. Thus, the approach to Education Sustainable Development (ESD) can be implemented successfully. The five constructs developed in the model also can provide students with a sense of awareness of environmental sustainability through a well-identified behavior.

\section{ACKNOWLEDGEMENTS}

This research was sponsored by RIMC UUM CODE S.0 14344, Graduate Development Research Grant provided by Universiti Utara Malaysia.

\section{REFERENCES}

[1] V. Brocx and M. Semeniuk, "The ' $8 \mathrm{Gs'-a} \mathrm{blueprint} \mathrm{for} \mathrm{Geoheritage,} \mathrm{Geoconservation,} \mathrm{Geo-education} \mathrm{and}$ Geotourism,” Aust. J. Earth Sci., vol. 66, no. 6, pp. 803-821, 2019.

[2] National Geographic, "Geo-education: Essential preparation for an interconnected world," 2019. [Online]. Available: https://www.nationalgeographic.org/education/geo-education-essential-preparation-interconnectedworld.

[3] J. Wooltorton, S. Wilkinson, A. Horwitz, P. Bahn, S. Redmond, and J. Dooley, "Sustainability and action research in universities," Int. J. Sustain. High. Educ., vol. 16, no. 4, pp. 424-439, 2015.

[4] K. S. Fielding and B. W. Head, "Determinants of young Australians' environmental actions:The role of responsibility attributions, locus of control, knowledge and attitudes," Environ. Educ. Res., vol. 18, no. 2, pp. 171-186, 2012, doi: 10.1080/13504622.2011.592936.

[5] K. Y. Foo, "A vision on the role of environmental higher education contributing to the sustainable development in Malaysia," J. Clean. Prod., vol. 61, pp. 6-12, 2013, doi: 10.1016/j.jclepro.2013.05.014. 
[6] H. Mahat, S. Ahmad, M. Suhaily, Y. Che, and N. Ali, "Pendidikan pembangunan lestari-hubungan kesedaran antara ibu bapa dengan pelajar," Geogr. Malaysian J. Soc. Sp., vol. 10, no. 5, pp. 71-84, 2014.

[7] S. R. Suwanlee, "Analysis of Geo-informatics Teaching Capabilities of Teachers in Thai High Schools by Geographic Information System,” J. Educ. Practice, vol. 3, no. 11, pp. 30-37, 2012.

[8] Y. Mohmadisa, H. M Suhaily, Pembangunan dan alam sekitar di Malaysia. Tanjung Malim: Universiti Pendidikan Sultan Idris, 2005.

[9] A. M. Zohir and S. I. Sharifah, "Kesediaan guru pelatih USM dalam menangani isu pembangunan lestari," Seminar Kebangsaan JPPG, Education for Sustainable Development, 2005.

[10] C. Chan, "Geo-disasters vs. climate change: Enhancing student's learning via a course-embedded project," in International Conference on Industrial Engineering and Operations Management, 2015, pp. 1-6.

[11] S. W. Bednarz, S. Heffron, and N. T. Huynh, A Road Map for 21st Century Geography Education: Geography Education Research. Association of American Geographers. Washington, DC, 2013.

[12] M. S. M. Saleh, "Media and environmental Non-Governmental Organizations (ENGOs) roles in environmental eustainability communication in Malaysia," Discourse Commun. Sustain. Educ., vol. 8, no. 1, pp. 90-101, 2017.

[13] H. I. Kwami, A. H. Ismail, A. I. Che-Ani, H. Omar, and M. Mamat, "Sustainable operation practices: The case of Universiti Kebangsaan Malaysia,” J. Eng. Sci. Technol., vol. 12, Special Issue, pp. 74-85, 2017.

[14] E. Yli-Panula, E. Jeronen, and P. Lemmetty, "Teaching and learning methods in geography promoting sustainability," Educ. Sci., vol. 10, no. 1, 2020, doi: 10.3390/educsci10010005.

[15] W. L. Filho, L. L. Brandli, P. Castro, and J. Newman, Handbook of theory and practice of sustainable sevelopment in higher education. Springer International Publishing, 2017.

[16] M. F. M. Yaakob, et al., "A quest for experts' Consensus on the Geo-education module using Fuzzy Delphi analysis," Univers. J. Educ. Res., vol. 8, no. 7, pp. 3189-3203, 2020, doi: 10.13189/ujer.2020.080748.

[17] UNESCO, "Education for people and planet: creating sustainable futures for all," Global Education Monitoring Report, 2016.

[18] M. Mukaddes and M.F. Agnello, "Sustainability/GREEN: Challenges and changes for educators and the engineering curriculum," American Society for Engineering Education (ASEE) Annual Conference and Exposition Proceedings, 2009.

[19] E. D. Tilbury, R. B. Stevenson, J. Fien, and D. Schreuder, Education and Sustainability: Responding to the Global Challenge. IUCN Commission on Education and Communication (CEC), 2003.

[20] S. Yue, Y. Wen, M. Chen, G. Lu, D. Hu, and F. Zhang, "A data description model for reusing, sharing and integrating geo-analysis models," Environ. Earth Sci., vol. 74, no. 10, pp. 7081-7099, 2015, doi: 10.1007/s12665015-4270-5.

[21] UNESCO, "Education for Sustainable Development," en.unesco.org 2010. [Online]. Available: http://www.unesco.org/education/desd.

[22] HK. Doost, Z. Sanusi, T. F. Faridd, and G. Jegatesen "Institutions of higher education and partnerships in education for sustainable development: Case study of the regional centre of expertise (RCE) Penang, Malaysia," $J$. Sustain. Dev., vol. 4, no. 3, pp. 108-117, 2011.

[23] A. Hazura, "Hubungan antara penghayatan agama, kepercayaan epistemologi serta pengetahuan alam sekitar pelajar muslim dengan sikap dan tingkah laku terhadap alam sekitar," Universiti Sains Malaysia, 2009.

[24] L. Cohen, L. Manion, P. Lecturer, K. Morrison, and S. Lecturer, Research methods in education. London: Routledge, 2011.

[25] J. F. Hair, W. C. Black, B. J. Babin, and R. E. Anderson, Multivariate Data Analysis, 7th Ed. Pearson Prentice Hall, 2010.

[26] M. Faiz, B. Mohd, J. Nordin, and B. Yunus, "An Evaluation of Measurement Model for Malaysian Teacher Work Competencies: The Confirmatory Factor Analysis Approach," International Journal of Academic Research in Business and Social Sciences, vol. 6, no. 11, pp. 52-64, 2016, doi: 10.6007/IJARBSS/v6-i11/2373.

[27] J. F. Hair, M. Sarstedt, T. M. Pieper, and C. M. Ringle, "The Use of Partial Least Squares Structural Equation Modeling in Strategic Management Research: A Review of Past Practices and Recommendations for Future Applications," Long Range Plann., vol. 45, no. 5-6, pp. 320-340, 2012.

[28] F. L. David and C. Fornell, "Evaluating Structural Equation Models with Unobservable Variables and Measurement Error," J. Mark. Res., vol. 18, no. 1, pp. 39-50, 1981.

[29] M. R. Yusof, M. Y. M. Faiz, and M. Y. Ibrahim, "Measurement model of teaching competency of secondary school teachers in Malaysia," Int. J. Emerg. Technol. Learn., vol. 14, no. 20, pp. 157-164, 2019.

[30] B. M. Byrne, Structural Equation Modelling with AMOS: Basic Concepts, Applications and Programming, 2 nd ed. New York: Routledge, Taylor and Francis Group, 2010.

[31] M. Y. Ibrahim, M. R. Yusof, M. F. M. Yaakob, and Z. Othman, "Communication Skills: Top Priority of Teaching Competency," International Journal of Learning, Teaching and Educational Research, vol. 18, no. 8, pp. 17-30, 2019.

[32] L. S. Meyers, G. Gamst, and A. J. Guarino, Applied multivariate research: Design and interpretation, 2 nd Ed. London: Sage Publication, 2013.

[33] B. Balakrishnan, F. Tochinai, and H. Kanemitsu, "Perceptions and attitudes towards sustainable development among Malaysian undergraduates," Int. J. High. Educ., vol. 9, no. 1, pp. 44-51, 2020, doi: 10.5430/ijhe.v9n1p44.

[34] S. Keesstra, et al., "Soil-related sustainable development goals: Four concepts to make land degradation neutrality and restoration work," Land, vol. 7, no. 4, 2018, doi: 10.3390/land7040133. 